\title{
Peran Pariwisata Raja Ampat Dalam Perkembangan Ekonomi Kawasan
}

\author{
Ery Atmodjo 1 \\ ${ }^{1}$ Dosen Jurusan Sosial Ekonomi Pertanian, Universitas Papua
}

Permalink/DOI: https://doi.org/10.36883/jfres.v4i2.61

Received: September 2021; Accepted: September 2021; Published: September 2021

\begin{abstract}
Abstrak
Pariwisata merupakan industri multi sektor yang berpotensi mendorong investasi, konsumsi, serta menciptakan lapangan pekerjaan. Pergerakan wisatawan dari daerah asal menuju daya tarik wisata dapat berdampak terhadap perekonomian daerah transit yang disinggahi. Kajian ini menganalisis peran pariwisata Kabupaten Raja Ampat terhadap perkembangan ekonomi Kota Sorong yang merupakan kota transit bagi wisatawan yang berkunjung ke Kabupaten Raja Ampat. Pertumbuhan pariwisata Kabupaten Raja Ampat yang pesat berperan dalam pertumbuhan kunjungan wisatawan di Kota Sorong, namun tidak berdampak terhadap PDRB sektor pariwisata Kota Sorong.
\end{abstract}

Kata kunci: pariwisata, ekonomi kawasan, pertumbuhan ekonomi, Raja Ampat, Sorong

\begin{abstract}
Tourism is a multi-sector industry that has the potential to induce investment, consumption, and employment opportunity. Tourists' movement from their place of origin to tourism destination may have an impact on the regional economy of transit place. This study analyses the role of tourism of Raja Ampat Regency in the economic growth of Sorong Municipality as the transit city for tourists heading for Raja Ampat Regency. The steady growth of tourism of Raja Ampat Regency plays role in the growth of tourists arrival in Sorong Municipality but has no impact on the GDRP of the tourism sector of Sorong Municipality.
\end{abstract}

Keywords: tourism, regional economy, economy growth, Raja Ampat, Sorong

How to Cite: Atmodjo, Ery, (2021). Peran Pariwisata Raja Ampat Dalam Perkembangan Ekonomi Kawasan. JFRES: Journal of Fiscal and Regional Economy Studies, 4(2), 35 - 47, doi: https://doi.org/10.36883/jfres.v4i2.61.

\footnotetext{
Corresponding author:

E-mail: ery@unipa.ac.id
}

\section{PENDAHULUAN}

Industri pariwisata dunia mengalami pertumbuhan yang relatif stabil. Selama perode tahun 2009-2019 jumlah wisatawan dunia tumbuh rata-rata $5,1 \%$ per tahun, dengan pertumbuhan rata-rata wisatawan tertinggi di kawasan Asia dan Pasific sebesar $7,1 \%$ per 
tahun (World Tourism Organization (UNWTO), 2020). Industri pariwisata semakin dipandang sebagai sektor ekonomi yang penting dalam pembangunan ekonomi dan dijadikan sektor andalan dalam pembangunan ekonomi. Salah satu pertimbangan pentingnya kedudukan sektor pariwisata dalam pembangunan ekonomi adalah peran potensial sektor ini dalam pengentasan kemiskinan (Llorca-Rodríguez et al., 2017; Njoya \& Seetaram, 2017). Karena merupakan industri multi sektor, industri pariwisata juga berpotensi mendorong pertumbuhan ekonomi melalui pertumbuhan konsumsi dan investasi (Cahyadi, 2018; Fredman \& Yuan, 2011; Roudi et al., 2019). Karena bersifat jasa, tumbuhnya industri pariwisata dapat menyerap banyak tenaga kerja sehingga berpotensi mengurangi tingkat pengangguran (Aguayo, dkk., 2011; Truong, 2014; Wiranatha \& Suryawardani, 2017).

Kedudukan sektor pariwisata di Indonesia juga semakin penting dalam peningkatan perekenomian nasional. Raja Ampat merupakan tujuan wisata yang semakin populer di seluruh dunia, terutama bagi peminat wisata selam. Meskipun tidak menjadi kawasan wisaata unggulan untuk target peningkatan jumlah wisatawan, sektor pariwisata Raja Ampat terus tumbu secara signifikan. Kabupaten Raja Ampat berkembang menjadi kawasan wisata konservasi karena adanya kawasn konservasi perairan yang dibangun di kabupaten ini. Sektor pariwisata merupakan sektor unggulan di Kabupaten Raja Ampat untuk meningkatkan perekonomian daerah dan perekonomian masyarakat (Pemerintah Kabupaten Raja Ampat, 2014). Selain itu, sektor pariwisata juga dipilih menjadi cara untuk mendanai upaya-upaya konservasi terkait pengembangan kawasan konservasi di Kabupaten Raja Ampat (Atmodjo et al., 2017)

Berbeda dengan industri manufaktur yang produknya mengalir dari produsen menuju konsumen, pada industri pariwisata konsumen bergerak menuju produsen produk pariwisata, maka wisatawan berpotensi memberikan dampak pada perekonomian di sepanjang perjalanan menuju lokasi tujuan wisata. Hal ini menimbulkan pertanyaan mengenai bagaimana pertumbuhan pariwisata di suatu kawasan dapat menjadi pendorong perkembangan ekonomi bagi kawasan di sekitarnya, terutama yang menjadi loasi transit. Kedudukan geografis Kabupaten Raja Ampat dan kondisi fasilitas transportasi sedemikian rupa menyebabkan Kota Sorong menjadi kota transit bagi wisatawan yang berkunjung ke Kabupaten Raja Ampat. Kajian ini bertujuan menganalisis peran pariwisata Kabupaten Raja Ampat terhadap perkembangan ekonomi Kota Sorong sebagai kota transit bagi wisatawan yang berkunjung ke Kabupaten Raja Ampat.

\section{METODE PENELITIAN}

\section{Data}

Sumber utama data yang digunakan dalam kajian ini adalah data statistik yang dipublikasikan oleh Biro Pusat Statistik (BPS), khususnya BPS Kota Sorong dan BPS Kabupaten Raja Ampat, dan Unit Pelaksana Teknis Kawasan Konservasi Perairan Daerah Raja Ampat (UPTD KKPD Raja Ampat). Jenis data yang diperoleh dari publikasi BPS dan UPTD KKPD Raja Ampat adalah data kuantitatif. Meskipun secara umum struktur penyajian publikasi BPS seragam antara satu kabupaten/kota dan lainnya, komponen data yang dikandung setiap bagian/bab yang sama dalam laporan dari jenis yang sama tidak selalu sama. Sebagai contoh, Kabupaten Raja Ampat Dalam Angka menyajikan data wisatawan yang terdiri dari wisatawan mancanegara dan wisatawan domestik, sedangkan Kota Sorong Dalam Angka hanya menyajikan data wisatawan mancanegara. Di lain pihak, Kota Sorong Dalam Angka menyajikan data tamu hotel yang dirinci menurut kelas hotel dan asal wisatawan, yaitu wisatawan mancanegara dan wisatawan domestik.

Data statistik yang digunakan dalam kajian ini adalah data deret waktu (time series). Namun demikian, ketrsediaan data antara kedua daerah yang menjadi fokus pengamatan dan antar variabel yang diamati tidak sama. Data mengenai wisatawan Kabupaten Raja Ampat tersedia untuk periode tahun 2007 sampai tahun 2020, sedangkan data wisatawan Kota Sorong 
tersedia untuk periode tahun 2018 sampai tahun 2018. Sementara itu, data tamu hotel di Kota Sorong tersedia untuk periode tahun 2009 sampai 2019, sedangkan data produk domestik regional bruto (PDRB) Kota Sorong menurut lapangan usaha akomodasi dan makan minum tersedia untuk periode tahun 2009 sampai tahun 2020. Oleh karena itu analisis untuk setiap pasangan variabel disesuaikan dengan data yang tersedia.

Selain data kuantitatif yang diperoleh dari publikasi BPS, kajian ini juga menggunakan data kualitatif yang diperoleh melalui wawancara semi struktural dan observasi lapangan. Wawancara semi struktural dan observasi lapangan tersebut dilakukan peneliti selama melakukan pengumpulan data lapangan untuk keperluan studi doktoral antara tahun 2014 sampai 2019. Data kualitatif tersebut digunakan dalam bagian pembahasan, sebagai informasi tambahan untuk mendukung penjelasan mengenai keterkaitan antar variabel yang diamati.

\section{Metode Analisis}

Variabel yang digunakan sebagai pendekatan terhadap pariwisata di Kabupaten Raja Ampat adalah jumlah kunjungan wisatawan, baik wisatawan mancanegara maupun wisatawan domestik. Untuk pendekatan terhadap perkembangan ekonomi Kota Sorong, digunakan variabelvariabel jumlah kunjungan wisatawan mancanegara, jumlah wisatawan yang menginap di hotel baik wisatawan mancanegara maupun wisatawan domestik, jumlah kamar hotel, dan PDRB sektor pariwisata, yaitu penyedia akomodasi dan makan minum. Jumlah kunjungan wisatawan domestik Kota Sorong tidak dianalisis karena datanya tidak cukup tersedia.
Metode analisis untuk melihat peran pariwisata Kabupaten Raja Ampat dalam perkembangan ekonomi Kota Sorong adalah regresi linier. Data pariwisata Kota Sorong dan kabupaten Raja Ampat yang tersedia adalah data mulai tahun 2007 sampai tahun 2020. Namun demikian data untuk setiap variabel tidak selalu tersedia untuk setiap tahun. Oleh karena itu, data yang tersedia untuk dianalisis kurang dari 13 tahun. Dengan keadaan data seperti itu, analisis regresi yang dilakukan adalah analisis regresi sederhana. Analisis regresi panel tidak dipilih dalam kajian ini karena data yang dianalisis adalah data serial, bukan kombinasi anatara data serial dan data lintaspotong (cross-section). Karena data yang digunakan adalah data serial, maka ada konsekwensi korelasi serial, sehingga dalam kajian ini pemeriksaan asumsi korelasi serial tidak dilakukan. Pemeriksaan asumsi klasik analisis regresi yang dilakukan hanya terhadap asumsi homoskedatisitas. Uji Glejser digunakan untuk pemeriksaan asumsi klasik homoskedastisitas (Paolella, 2018).

Analisis regresi linier sederhana terdiri dari 6 pasangan variabel deskriptor dan variabel respons. Namun demikian, dengan asumsi ada potensi pengaruh variabel lag pada variabel jumlah kamar hotel dan variabel PDRB sektor pariwisata, maka dilakukan analisis regresi lag pada kedua variabel tersrebut untuk memeriksa adanya pengaruh variabel lag. Adapun Simbol untuk variabel-variabel yang dianalisis disajikan pada Tabel 1, sedangkan model regresi untuk setiap analisis regresi disajikan pada Tabel 2. Nilai kritis uji statistik $\alpha$ yang digunakan untuk uji signifikansi model regresi, koefisien regresi dan uji asumsi homoskedastisitas (uji Glejser) adalah 0,1. Dengan kata lain, tingkat kepercayaan dari analisis yang dilakukan adalah $90 \%$. 
Tabel 1. Simbol Variabel-variabel yang Diamati

\begin{tabular}{cll}
\hline No. & \multicolumn{1}{c}{ Variabel } & \multicolumn{1}{c}{ Simbol } \\
\hline 1 & Jumlah kunjungan wisatawan mancanegara Kabupaten Raja Ampat & WMR \\
2 & Jumlah kunjungan wisatawan domestik Kabupaten Raja Ampat & WDR \\
3 & Jumlah kunjungan wisatawan Kabupaten Raja Ampat (mancanegara dan domestik) & WR \\
4 & Jumlah kunjungan wisatawan Kota Sorong & WMS \\
5 & Jumlah wisatawan mancanegara yang menginap di hotel Kota Sorong & TWMS \\
6 & Jumlah wisatawan domestik yang menginap di hotel Kota Sorong & TWDS \\
7 & Jumlah wisatawan yang menginap di hotel kota sorong & TWS \\
8 & Jumlah kamar hotel Kota Sorong & KHS \\
9 & Variabel lag jumlah kamar hotel Kota Sorong & KHS $_{\mathrm{t}-1}$ \\
10 & PDRB sektor pariwisata Kota Sorong & PDRBS \\
11 & Variabel lag PDRB sektor pariwisata Kota Sorong & PDRBS $_{\mathrm{t}-1}$ \\
\hline
\end{tabular}

Tabel 2. Pasangan Variabel pada Analisis Regresi

\begin{tabular}{|c|c|c|}
\hline No. & Pasangan Variabel & Keterangan \\
\hline 1 & WMS - WMR & $\begin{array}{l}\text { Regresi jumlah kunjungan wisatawan mancanegara Kabupaten Raja } \\
\text { Ampat terhadap jumlah kunjungan wisatawan mancanegara Kota } \\
\text { Sorong }\end{array}$ \\
\hline 2 & TWMS - WMR & $\begin{array}{l}\text { Regresi jumlah kunjungan wisatawan mancanegara terhadap jumlah } \\
\text { kunjungan wisatawan mancanegara yang menginap di hotel Kota } \\
\text { Sorong }\end{array}$ \\
\hline 3 & TWDS - WDR & $\begin{array}{l}\text { Regresi jumlah kunjungan wisatawan domestik Kabupaten Raja } \\
\text { Ampat terhadap jumlah wisatawan domestik yang menginap di } \\
\text { hotel Kota Sorong }\end{array}$ \\
\hline 4 & TWS - WR & $\begin{array}{l}\text { Regresi jumlah kunjungan wisatawan Kabupaten Raja Ampat } \\
\text { terhadap jumlah wisatawan yang menginap di hotel Kota Sorong }\end{array}$ \\
\hline 5 & KHS - WR & $\begin{array}{l}\text { Regresi jumlah kunjungan wisatawan Kabupaten Raja Ampat } \\
\text { terhadap jumlah kamar hotel Kota Sorong }\end{array}$ \\
\hline $5 \mathrm{a}$ & $\mathrm{KHS}-\mathrm{KHS}_{\mathrm{t}-1}+\mathrm{WR}$ & $\begin{array}{l}\text { Regresi variabel lag jumlah kamar hotel Kota Sorong dan jumlah } \\
\text { kunjungan wisatawan Kabupaten Raja Ampat terhadap jumlah } \\
\text { kamar hotel Kota Sorong }\end{array}$ \\
\hline 6 & PDRBWS - WR & $\begin{array}{l}\text { Regresi jumlah kunjungan wisatawan Kabupaten Raja Ampat } \\
\text { terhadap PDRB sektor pariwisata Kota Sorong }\end{array}$ \\
\hline $6 a$ & PDRBWS - PDRBWS $\mathrm{P}_{\mathrm{t}-1}+\mathrm{WR}$ & $\begin{array}{l}\text { Regresi variabel lag PDRB sektor pariwisata Kota Sorong dan } \\
\text { jumlah kunjungan wisatawan Kabupaten Raja Ampat terhadap } \\
\text { PDRB sektor pariwisata Kota Sorong }\end{array}$ \\
\hline
\end{tabular}

\section{HASIL PENELITIAN}

\section{Karakteristik Pariwisata Kota Sorong dan Kabupaten Raja Ampat}

Tabel 3. Daya Tarik Wisata Kota Sorong

\begin{tabular}{cll}
\hline No. & Daya Tarik Wisata & Jenis Wisata \\
\hline 1 & Pantai Tanjung Kasuari & Pantai \\
2 & Pulau Raam & Pantai dan laut \\
3 & Pulau Soop & Pantai dan laut \\
4 & Pulau Doom & Pantai dan laut \\
5. & Pulau Dofior & Laut \\
6. & Tembok Berlin & Laut dan kuliner \\
7. & Hutan Wisata Arboretum & Hutan wisata \\
\hline
\end{tabular}

Sumber: BPS Kota Sorong, 2009

Karakteristik pariwisata Kabupaten Raja Ampat berbeda dengan pariwisata Kota Sorong. Daya tarik wisata yang ada dan dipromosikan oleh kedua daerah tersebut mencerminkan karakteristik pariwisata di daerah masingmasing. Daya tarik wisata Kota Sorong disajikan pada Tabel 3 dan daya tarik wisata Kabupaten Raja Ampat disajikan pada Tabel 4.

Tabel 4. Daya Tarik Wisata Kabupaten Raja Ampat

\begin{tabular}{clc}
\hline No. & \multicolumn{1}{c}{$\begin{array}{c}\text { Jenis } \\
\text { Wisata }\end{array}$} & $\begin{array}{c}\text { Jumlah Daya Tarik } \\
\text { Wisata }\end{array}$ \\
\hline 1 & Alam & 27 \\
2 & Alam (Selam) & 26 \\
3 & Budaya & 1 \\
4 & Minat Khusus & 17 \\
5 & Wisata Modern & 1 \\
\hline & Jumlah & 72 \\
\hline
\end{tabular}

Sumber: Dinas Kebudayaan dan Pariwisata Kabupaten Raja Ampat 
Tabel 3 menunjukkan bahwa daya tarik wisata di Kota Sorong jumlahnya relatif terbatas, kurang bervariasi, dan umumnya merupakan wisata pantai dan laut. Daya tarik wisata di Kota Sorong terletak di sekitar Kota Sorong. Lokasi daya tarik terjauh adalah Pulau Soop, yang dapat dicapai dengan perahu motor tempel dalam waktu 15 menit.

Daya tarik wisata di Kabupaten Raja Ampat bervariasi dan banyak jumlahnya, didominasi oleh wisata alam dan wisata alam selam. Objek wisata dari jenis wisata minat khusus di Kabupaten Raja Ampat juga cukup bervariasi, seperti wisata bentang alam (goa, gunung, trekking) dan pengamatan burung. Lokasi daya tarik wisata di Kabupaten Raja Ampat tersebar luas dengan lebih dari 200 lokasi wisata alam selam. Jumlah lokasi daya tarik wisata alam selam yang dicantumkan dalam Tabel 4 adalah lokasi-lokasi yang paling sering dikunjungi, sebagian besar di Distrik Meos Mansar. Untuk mendorong peran serta masyarakat Pemerintah Kabupaten Raja Ampat menetapkan 24 kampung sebagai kampung wisata yang tersebar di 10 distrik (BPS Kabupaten Raja Ampat, 2021).

Secara umum karakeristik pariwisata Kota Sorong mirip dengan karakteristik pariwisata Kabupaten Raja Ampat, yaitu wisata alam di kawasan pesisir. Namun demikian, pariwisata Kabupaten Raja Ampat lebih spesifik pada wisata alam selam. Wisata alam pantai cenderung merupakan wisata massal, sedangkan wisata alam selam lebih condong pada wisata minat khusus. Wisata massal kurang sesuai untuk Kabupaten Raja Ampat, karena sebagian besar daya tarik wisata di Kabupaten Raja Ampat berada di kawasan konsevasi, khususnya KKPD Selat Dampier (Atmodjo et.al., 2017)

Tabel 5. Kunjungan Wisatawan di Kabupupaten Raja Ampat dan Kota Sorong Tahun 2007-2020

\begin{tabular}{crrrc}
\hline \multirow{2}{*}{ Tahun } & \multicolumn{3}{c}{ Kabupaten Raja Ampat } & Kota Sorong \\
\cline { 2 - 5 } & Mancanegara & Domestik & Total & Mancanegara \\
\hline 2007 & 1.118 & 79 & 1.197 & 145 \\
2008 & 2.839 & 335 & 3.174 & 308 \\
2010 & 3.466 & 405 & 3.871 & 47 \\
2011 & 4.628 & 790 & 5.418 & 292 \\
2012 & 6.178 & 1.849 & 8.027 & 149 \\
2013 & 7.244 & 2.060 & 9.304 & 136 \\
2014 & 10.157 & 4.006 & 14.163 & 253 \\
2015 & 10.759 & 7.691 & 18.450 & 297 \\
2016 & 12.011 & 10.251 & 22.262 & 324 \\
2017 & 13.616 & 12.472 & 26.088 & 547 \\
2018 & 18.841 & 17.250 & 36.091 & 535 \\
2019 & 23.099 & 20.811 & 43.910 & 208 \\
2020 & 24.090 & 22.285 & 46.375 & TA \\
\hline
\end{tabular}

Keterangan: TA=Tidak ada data

Sumber: BPS Kota Sorong, n.d, Publikasi BPS Kota Sorong, dan data tarif masuk wisatawan dari UPTD KKPD Raja Ampat.

\section{Kunjungan Wisatawan}

Tabel 5 menampilkan jumlah wisatawan yang berkunjung ke Kabupaten Raja Ampat dan Kota Sorong selama periode tahun 2007 sampai 2020 yang dirinci menurut asal wisatawan, yaitu wisatawan mancanegara dan wisatawan domestik. Tabel 5 menunjukkan bahwa kunjungan wisatawan di Kabupaten Raja Ampat dan Kota Sorong meningkat dari tahun ke tahun. Pada tahun 2020 jumlah wisatawan yang tercatat mengunjungi Kabupaten Raja Ampat menurun drastis akibat pandemi Covid-19. Kunjungan wisatawan di Kabupaten Raja Ampat didominasi oleh wisatawan mancanegara, namun dari tahun ke tahun jumlah wisatawan domesik ke Kabupaten Raja Ampat meningkat pesat hampir menyamai jumlah wisatawan mancanegara.

Pertumbuhan kunjungan wisatawan ke Kabupaten Raja Ampat secara keseluruhan dalam periode tahun 2007 sampai tahun 2019 sebesar $35,63 \%$ pe tahun. Pertumbuhan kunjungan wisatawan mancanegara ke Kabupaten Raja Ampat dalam periode itu sebesar 29,16\% per tahun, sedangkan 
pertumbuhan kunjungan wisatawan domestik ke Kabupaten Raja Ampat sebesar 60,03\% per tahun. Pada periode yang sama pertumbuhan kunjungan wisatawan mancanegara ke Kota Sorong hanya seperenam dari pertumbuhan kunjungan wisatawan mancanegara ke Kabupaten Raja Ampat, yaitu sebesar 6,33\% per tahun.

Pada periode tahun 2007-2011 wisatawan mancanegara di Kota Sorong didominasi wisatawan Asia, seperti wisatawan dari Malaysia, Hongkong, dan Jepang. Pada Tahun 2012 kunjungan wisatawan dari Cina ke Kota Sorong mulai meningkat. Pada tahun 2015 kunjungan wisatawan dari Amerika Serikat dan Eropa (Jerman, Perancis, Inggris) di Kota
Sorong mulai meningkat. Wisatawan mancanegara yang berkunjung ke Kabupaten Raja Ampat didominasi warga negara Amerika Serikat dan Eropa (Jerman, Belanda, Spanyol), namun kunjungan wisatawan asal Cina mulai meningkat sejak tahun 2017.

\section{Prasarana Akomodasi}

Data prasarana akomodasi yang disajikan dalam publikasi BPS Kota Sorong adalah hotel, yang dirinci menjadi hotel berbintang dan hotel melati (BPS Kota Sorong, 2013). Jumlah hotel, kapasitas hotel dan jumlah wisatawan yang menginap di hotel di Kota Sorong selama periode tahun 2007 sampai tahun 2019 disajian pada Tabel 6.

Tabel 6. Jumlah Hotel, Jumlah Kamar Hotel, dan Jumlah Tamu Hotel di Kota Sorong Tahun 2007-2019

\begin{tabular}{cccccc}
\hline \multirow{2}{*}{ Tahun } & \multirow{2}{*}{ Jumlah Hotel } & $\begin{array}{c}\text { Jumlah } \\
\text { Kamar Hotel }\end{array}$ & \multicolumn{3}{c}{ Jumlah Tamu } \\
\cline { 4 - 6 } & 23 & 718 & Mancanegara & Domestik & \multicolumn{1}{c}{ Total } \\
\hline 2007 & 23 & 701 & TA & TA & TA \\
2009 & 21 & 731 & 1.772 & 144.374 & 146.146 \\
2010 & $\mathrm{TA}$ & $\mathrm{TA}$ & 3.012 & 60.582 & 63.594 \\
2011 & 23 & 803 & 3.012 & 60.582 & 63.594 \\
2012 & 23 & 792 & 1.786 & 66.546 & 68.332 \\
2013 & 23 & 844 & 2.339 & 82.500 & 84.839 \\
2014 & 27 & 1.161 & 3.398 & 112.060 & 115.458 \\
2015 & 27 & 1.161 & 3.367 & 84.262 & 87.629 \\
2016 & 27 & 1.161 & 2.551 & 111.086 & 113.637 \\
2017 & 27 & 1.161 & 4.497 & 89.862 & 94.359 \\
2018 & 27 & 1.161 & 11.814 & 132.662 & 144.476 \\
2019 & 33 & 1.065 & 19.096 & 271.367 & 290.463 \\
\hline
\end{tabular}

Keterangan: TA = Tidak ada data

\section{Sumber: Publikasi BPS Kota Sorong}

Jumlah hotel di Kota Sorong mengalami peningkatan selama periode tahun 2007 sampai tahun 2019. Namun demikian pertumbuhan jumlah kamar sedikit lebih tinggi dibanding pertumbuhan jumlah hotel. Selama kurun waktu tahun 2007 sampai 2019 Jumlah hotel di Kota Sorong tumbuh sebesar $3,05 \%$ per tahun, sedangkan jumlah kamar hotel tumbuh sebesar $3,24 \%$ per tahun pada kurun waktu yang sama. Data pertumbuhan kamar hotel menunjukkan bahwa sejumlah hotel melakukan investasi dengan menambah jumlah kamar. Meskipun tidak besar, peningkatan pertumbuhan jumlah kamar hotel terjadi pada tahun 2014. Tabel 5 menunjukkan bahwa pada tahun 2013 terjadi lojakan kunjungan wisatawan baik ke Kabupaten Raja Ampat maupun ke Kota Sorong. Pada tahun 2013 kunjungan wisatawan ke Kota Sorong melonjak sebesar 52,22\% dan ke Kabupaten Raja Ampat melonjak sebesar 94,47\% dibanding tahun sebelumnya. Dapat disimpulkan bahwa pengusaha hotel melakukan investasi dengan menambah jumlah kamar pada tahun 2014 sebagai tanggapan terhadap lonjakan kunjungan wisatawan pada tahun 2013, dan perkiraan pertumbuhan jumlah wisatawan yang lebih pesat dibanding tahun-tahun sebelumnya. 
Meskipun berfluktuasi, jumlah wisatawan yang menginap di hotel di Kota Sorong mengalami pertumbuhan selama kurun waktu tahun 2009 sampai tahun 2019. Secara keseluruhan, jumlah wisatawan yang menginap di hotel di Kota Sorong mengalami pertumbuhan $7,11 \%$ per tahun. Jumlah wisatawan domestik yang menginap di hotel tumbuh sebesar $6,51 \%$ per tahun, sedangka jumlah wisatawan mancanegara yang meginap di hotel tumbuh pesat sebesar $26,84 \%$ per tahun. Pertumbuhan tamu hotel yang lebih tinggi dibanding pertumbuhan jumlah kamar hotel menunjukkan bahwa tingkat penghunian kamar hotel mengalami peningkatan. Tingkat penghunian kamar hotel di Kota Sorong pada tahun 2012 sebesar 46,84\%, pada tahun 2018 meningkat menjadi 52,56\%.

Tabel 7. Jumlah Prasarana Akomodasi di Kabupaten Raja Ampat Tahun 2020

\begin{tabular}{lll}
\hline No. & Jenis Akomodasi & Jumlah \\
\hline 1 & Resort & 30 \\
2 & Cottage & 4 \\
3 & Hotel & 4 \\
5 & Penginapan & 24 \\
6 & Homestay & 200 \\
7 & Liveaboard & 69 \\
\hline
\end{tabular}

Sumber: BPS Kabupaten Raja Ampat, 2021

Prasarana akomodasi di Kabupaten Raja Ampat terdiri dari hotel, resort, cottage, penginapan dan homestay. Selain itu, sebagian wisatawan yang berkunjung ke Kabupaten Raja Ampat tinggal di perahu wisata atau liveaboard. Jumlah prasarana akomodasi di Kabupaten Raja Ampat disajikan pada Tabel 7.

Hotel dan penginapan (inn) umumnya berada di Kota Waisai sebagai ibu kota Kabupaten Raja Ampat, sedangkan resort, cottage dan homestay berada di luar Kota Waisai, di sekitar lokasi daya tarik wisata. Resort, cottage dan homestay terpusat di Distrik Meos Mansar dan Distrik Waigeo Selatan yang merupakan konsentrasi kegiatan pariwisata di Kabupaten Raja Ampat (BPS Kabupaten Raja Ampat, 2021). Menurut peraturan daerah Kabupaten Raja Ampat homestay adalah jenis akomodasi yang dimiliki dan diusahakan oleh orang asli Papua (OAP).

\section{Pertumbuhan Sektor Pariwisata}

Lapangan usaha yang mencerminkan pertumbuhan sektor pariwisata dalam laporan BPS adalah penyediaan akomodasi dan makan minum. Pendapatan domestik regional bruto (PDRB) Kota Sorong untuk sektor ini disajikan pada Tabel 8.

Tabel 8. PDRB Sektor Penyediaan Akomodasi dan Makan Minum Kota Sorong Tahun 2009-2020 Menurut Harga Konstan Tahun 2010 (Dalam Milyar Rupiah)

\begin{tabular}{cccc}
\hline Tahun & $\begin{array}{c}\text { PDRB Sektor Penyediaan } \\
\text { Akomodasi dan Makan Minum }\end{array}$ & PDRB Kota Sorong & $\begin{array}{c}\text { Kontribusi Setor Penyediaan } \\
\text { Akomodasi dan Makan Minum }\end{array}$ \\
\hline 2009 & 78,59 & $4.586,81$ & 1,71 \\
2010 & 88,65 & $4.996,51$ & 1,77 \\
2011 & 91,89 & $5.323,44$ & 1,73 \\
2012 & 96,45 & $5.837,36$ & 1,65 \\
2013 & 99,10 & $6.527,73$ & 1,52 \\
2014 & 103,92 & $7.317,73$ & 1,42 \\
2015 & 111,46 & $8.069,06$ & 1,38 \\
2016 & 167,90 & $12.363,25$ & 1,36 \\
2017 & 186,30 & $13.821,69$ & 1,35 \\
2018 & 210,65 & $15.097,47$ & 1,40 \\
2019 & 233,80 & $15.822,75$ & 1,48 \\
2020 & 235,06 & $15.600,51$ & 1,51 \\
\hline
\end{tabular}

Sumber: Publikasi BPS Kota Sorong 
Pendapatan domestik regional bruto sektor penyediaan akomodasi dan makan minum selama periode 2009 sampai 2020 tumbuh secara bertahap. Pertumbuhan rata-rata sektor penyediaan akomodasi dan makan minum sebesar $10,47 \%$ per tahun, dan PDRB Kota Sorong tumbuh rata-rata $11,77 \%$ per tahun. Dengan demikian tingkat pertumbuhan PDRB sektor penyediaan akomodasi makan dan minum hampir sama dengan tingkat pertumbuhan PDRB Kota Sorong secara keseluruhan. Namun demikian, kontribusi sektor ini berfluktuasi dari tahun ke tahun. Tabel 8 menunjukkan bahwa fluktuasi kontribusi sektor penyediaan akomodasi dan makan minum disebabkan oleh fluktuasi PDRB Kota Sorong. Meskipun terjadi peningkatan dari tahun ke tahun, kontribusi tertinggi sektor pariwisata terhadap PDRB Kota Sorong justru terjadi pada tahun-tahun awal periode analisis, dan belum pernah kembali mencapai tingkat kontribusi semula. Hal ini memberikan gambaran bahwa pertumbuhan sektor pariwisata lebih rendah dari pertumbuhan sektor-sektor lainnya.

Tabel 9. Hasil Analisis Regresi Antara Variabel-variabel Pariwisata Kabupaten Raja Ampat dan Variabel-variabel Pariwisata dan PDRB Sektor Pariwisata Kota Sorong

\begin{tabular}{llcccc}
\hline No. & \multicolumn{1}{c}{ Pasangan Variabel } & $\begin{array}{c}P \text {-Value } \\
\text { Persamaan } \\
\text { Regresi }\end{array}$ & $\begin{array}{c}\text { P-Value Uji } \\
\text { Glejser }\end{array}$ & $\begin{array}{c}\text { P-Value } \\
\text { Koefisien } \\
\text { Regresi }\end{array}$ & $\begin{array}{c}\text { Koefisien } \\
\text { Regresi }\end{array}$ \\
\hline 1 & WMS - WMR & 0,09 & 0,11 & 0,09 & 0,012 \\
2 & TWMS - WMR & 0,00 & 0,16 & 0,00 & 0,620 \\
3 & TWDS - WDR & 0,04 & 0,11 & 0,04 & 4,687 \\
4 & TWS - WR & 0,03 & 0,12 & 0,03 & 2,786 \\
5 & KHS - WR & 0,00 & 0,34 & 0,00 & 0,010 \\
$5 \mathrm{a}$ & KHS - KHS & 0,00 & 0,61 & 0,07 & 0,763 \\
& & & & 0,85 & 0,001 \\
6 & PDRBWS - WR & 0,00 & 0,31 & 0,00 & 0,002 \\
6a & PDRBWS - PDRBWS & 0,65 & 0,00 & 0,947 \\
& & 0,00 & 0,65 & 0,05 & 0,001 \\
\hline
\end{tabular}

Sumber: Data Diolah, 2021

Peran Pariwisata Kabupaten Raja Ampat terhadap Perkembangan Sektor Pariwisata Kota Sorong

Parameter-parameter yang digunakan sebagai variabel perkembangan sektor pariwisata Kota Sorong adalah kunjungan wisatawan mancanegara, jumlah kamar hotel, jumlah tamu hotel, dan PDRB Kota Sorong dari sektor penyediaan akomodasi dan makan minum. Kunjungan wisatawan domestik tidak disertakan dalam kajian ini karena tidak diperoleh datanya. Parameter-parameter pariwisata Kabupaten Raja Ampat yang digunakan dalam kajian ini adalah jumlah kunjungan wisatawan ke Kabupaten Raja Ampat, baik wisatawan mancanegara maupun wisatawan domestik. Parameter-parameter pariwisata Kabupaten Raja Ampat merupakan variabel perdiktor dan parameter-parameter pariwisata Kota Sorong merupakan variabel respons. Hasil analisis regresi linier sederhana untuk setiap pasangan variabel yang dianalisis disajikan pada Tabel 9.
Tabel 9 menampilkan hasil analisis regresi linier terhadap 6 (enam) pasangan variabel prediktor dan variabel respons peran pariwisata Kabupaten Raja Ampat terhadap perkembangan eknomi Kota Sorong. Analisis nomor urut 5a merupakan lanjutan dari analisis nomor urut 5 untuk melihat apakah penambahan variabel prediktor berupa lag dari variabel respon dapat memperbaiki nilai parameter-parameter statistik uji regresi. Demikian pula, analisis nomor urut 6a merupakan lanjutan dari analisis nomor urut 6 untuk melihat apakah penambahan variabel berupa lag dari variabel respon dapat memperbaiki nilai parameter-parameter uji statistik regresi.

Tabel 9 menunjukkan bahwa nilai P-value uji persamaan regresi semua pasangan variabel lebih kecil dibanding nilai kritis $\alpha$ yang dijadikan kriteria uji dalam kajian ini, yaitu 0,1 . Dengan demikian semua pasangan persamaan regresi dapat digunakan untuk menganalisis keterkaitan antara pariwisata Kabupaten Raja Ampat dengan perkembangan ekonomi Kota 
Sorong. Nilai P-value uji Glejser semua pasangan variabel lebih besar dari nilai $\alpha$. Dengan demikian tidak ada heteroskedatisitas pada semua persamaan regresi.

Kecuali nomor urut 5a, nilai P-value dari koefisien regresi dari variabel prediktor lebih kecil dari nilai $\alpha$, sehingga dapat disimpulkan bahwa variabel prediktor pada persamaanpersamaan regresi selain analisis regresi nomor urut 5a dapat dijadikan penduga bagi variabel respons dalam setiap persamaan regresi bersangkutan. Pada analisis regresi nomor urut 5, yaitu regresi jumlah kunjungan wisatawan Kabupaten Raja Ampat (WR) terhadap pertumbuhan jumlah kamar hotel di Kota Sorong, (KHS) P-value persamaan regresi dan koefisien regresi lebih kecil dari $\alpha$ yang telah ditetapkan, dan P-value uji Glejser lebih besar dibanding nilai $\alpha$ yang telah ditetapkan yaitu 0,1 sehingga persamaan regresi dan koefisien regresi signifikan, dan tidak ada masalah heteroskedastisitas. Ketika ditambahkan variabel lag sebagai variabel prediktor $\left(\mathrm{KHS}_{\mathrm{t}-1}\right)$ kepada analisis regresi nomor urut 5 sehingga menjadi sebagaimana pada nomor urut 5a, Pvalue persamaan regresi lebih kecil dari nilai $\alpha$, P-value uji Glejser lebih besar dari nilai $\alpha$, namun P-value dari koefisien regresi dari variabel prediktor jumlah kunjungan wisatawan Kabupaten Raja Ampat (WR) menjadi 0,85, lebih besar dari nilai $\alpha$ yang telah ditetapkan yaitu 0,1 . Dengan demikian variabel kunjungan wisatawan Kabupaten Raja Ampat tidak dapat menjadi penduga bagi pertumbuhan kamar hotel Kota Sorong dengan menggunakan hasil analisis nomor urut 5a. Hubungan antara variabel jumlah kunjungan wisatawan Kabupaten Raja Ampat dengan variabel jumlah kamar hotel di Kota Sorong dijelaskan menggunakan persamaan regresi dari hasil analisis nomor urut 5. P-value koefisien regresi variabel lag $\left(\mathrm{KHS}_{\mathrm{t}}\right.$ 1) yang lebih kecil dari nilai $\alpha$ pada hasil analisis regresi nomor urut 5a menunjukkan bahwa variabel jumlah kamar hotel di Kota Sorong pada suatu tahun berpengaruh terhadap jumlah kamar hotel di Kota Sorong pada tahun berikutnya.

Pada analisis regresi nomor urut 6a, yaitu dengan menambahkan variabel prediktor berupa lag dari variabel respons PDRB sektor pariwisata Kota Sorong $\left(\mathrm{PDRBWS}_{\mathrm{t}-1}\right)$ kepada persaman regresi pada analisis regresi nomor ururt 6, P-value persamaan regresi lebih kecil daripada nilai $\alpha$, dan P-value uji Glejser lebih besar dari $\alpha$, yang menunjukkan bahwa persamaan regresi yang dihasilkan dari analisis regresi nomor urut 6 a signifikan dan tidak terdapat heteroskedastisitas. P-value koefisien regresi dari variabel perdiktor jumlah kunjungan wisatawan Kabupaten Raja Ampat meningat menjadi 0,05 , akan tetapi masih lebih rendah dari nilai $\alpha$ yang ditetapkan sehingga variabel prediktor ini dapat menjadi penduga terhadap variabel respons PDRB Kota Sorong dengan menggunakan persamaan regresi dari hasil analisis regresi nomor urut 6a. Hasil analis regresi nomor urut 6 juga mengisolasi pengaruh variabel lag dari analisis regresi nomor urut 6 . P-value koefisien regresi dari variabel lag $\left(\right.$ PDRBWS $\left._{\mathrm{t}-1}\right)$ yang lebih kecil dari nilai $\alpha$ pada analisis regresi nomor urut 6a menunjukan bahwa PDRB sektor pariwisata Kota Sorong pada suatu tahun berpengaruh terhadap PDRB sektor tersebut di tahun berikutnya.

Analisis regresi nomor urut 1 pada Tabel 9 yaitu antara variabel prediktor jumlah kunjungan wisatawan mancanegara Kabupaten Raja Ampat (WMR) dengan variabel respons jumlah kunjungan wisatawan Kota mancanegara Sorong (WMS) menghasilkan persamaan regresi sebagai berikut:

$$
\text { WMS }=159.863+0,012 \mathrm{WMR}
$$

Persamaan regresi di atas dapat dimaknai bahwa untuk setiap peningkatan 1.000 orang kunjungan wisatawan mancanegara Kabupaten Raja Ampat, maka kunjungan wisatawan mancanegara di Kota Sorong akan meningkat sebanyak 12 orang. Persamaan regresi ini menunjukkan bahwa pengaruh perkembangan pariwisata Kabupaten Raja Ampat yang diukur dari pertumbuhan kunjungan wisatawan mancanegara sangat kecil pengaruhnya terhadap pertumbuhan sektor pariwisata Kota Sorong yang diukur dari kunjungan wisatawan mancanegara.

Analisis regresi nomor urut 2 pada Tabel 9 yaitu antara variabel prediktor jumlah kunjungan wisatawan Kabupaten Raja Ampat dengan variabel respons jumlah wisatawan mancanegara yang menginap di hotel di Kota Sorong menghasilkan persamaan regresi sebagai berikut:

TWMS $=-2406,79+0,620 \mathrm{WMR}$ 
Persamaan regresi di atas dapat dimaknai bahwa untuk setiap peningkatan 10 orang kunjungan wisatawan mancanegara Kabupaten Raja Ampat, maka wisatawan mancanegara yang menginap di Kota Sorong bertambah sebanya 6 orang. Jika dibandingkan dengan hasil analisis regresi nomor (1), persamaan regresi nomor (2) menunjukkan pengaruh yang cukup berarti dari pariwisata Kabupaten Raja Ampat terhadap perkembangan sektor pariwisata Kota Sorong khususnya pada sektor perhotelan, yaitu jumlah tamu mancanegara yang menginap di Kota Sorong.

Analisis regresi nomor urut 3 pada Tabel 9 yaitu antara variabel prediktor jumlah kunjungan wisatawan domestik Kabupaten Raja Ampat dengan variabel respons wisatawan domestik yang menginap di hotel di Kota Sorong menghasilkan persamaan regresi sebagai berikut:

TWDS $=67978.71+4,687 \mathrm{WDR}$

Persamaan regresi nomor (3) dapat dimaknai bahwa untuk setiap orang pertambahan kunjungan wisatawan domestik Kabupaten Raja Ampat, terdapat pertambahan jumlah wisatawan domestik yang menginap di hotel Kota Sorong sebanyak 4 sampai orang. Persamaan regresi ini menunjukkan pengaruh yang sangat berarti dari kunjungan wisatawan domestik Kabupaten Raja Ampat terhadap jumlah wisatawan domestik yang menginap di hotel Kota Sorong.

Analisis regresi nomor urut 4 pada Tabel 9 yaitu antara variabel preditor jumlah kunjungan wisatawan Kabupaten Raja Ampat dengan variabel respons jumlah wisatawan yang menginap di hotel di Kota Sorong menghasilan persamaan regresi sebagai berikut:

TWS $=56422,85+2,79 \mathrm{WR}$

Persamaan regresi nomor (4) dapat dimaknai bahwa untuk setiap orang pertambahan kunjungan wisatawan ke Kabupaten Raja Ampat, terdapat pertambahan jumlah wisatawan yang menginap di hotel di Kota Sorong sebanyak 2 sampai 3 orang wisatawan. Persamaan regresi ini menunjukkan pengaruh yang sangat berarti dari perkembangan pariwisata Kabupaten Raja Ampat terhadap perkembangan sektor pariwisata Kota Sorong, yang diukur dengan jumlah wisatawan yang menginap di Kota Sorong.
Analisis regresi nomor urut 5 pada Tabel 9 yaitu antara variabel prediktor kunjungan wisatawan Kabupaten Raja Ampat dan variabel respons jumlah kamar hotel di Kota Sorong menghasilkan persamaan regresi sebagai berikut:

KHS $=749,95+0,010 \mathrm{WR}$

Persamaan regresi nomor (5) dapat dimaknai bahwa untuk setiap peningkatan kunjunngan wisatawan Kabupaten Raja Ampat sebanyak 10 orang terdapat peningkatan 1 kamar hotel di Kota Sorong. Persamaan regresi ini menunjukkan pengaruh yang cukup berarti dari perkembangan pariwisata Raja Ampat berupa kunjungan wisatawan terhadap perkembangan sektor pariwisata Kota Sorong berupa pertumbuhan jumlah kamar hotel.

Analisis regresi nomor urut 6 a pada Tabel 9 merupakan regresi linier berganda dengan dua variabel prediktor yaitu variabel lag PDRB Kota Sorong dan variabel jumlah kunjungan wisatawan Kabupaten Raja Ampat, dengan variabel respons PDRB sektor pariwisata Kota Sorong. Analisis regresi ini menghasilkan persamaan regresi sebagai berikut:

PDRBWS $=6,786+0,947$ PDRBWSt $-1+$ 0,001 WR...............................(6a)

Persamaan regresi nomor (6a) dapat dimaknai bahwa setiap peningkatan 1.000 orang wisatawan Kabupaten Raja Ampat, PDRB sektor pariwisata Kota Sorong meningkat sebesar Rp 1.000.000 (satu juta rupiah). Persamaan regresi ini menunjukkan bahwa perkembangan pariwisata Kabupaten Raja Ampat berupa kunjungan wisatawan hampir tidak ada penngaruhnya terhadap perkembangan sektor pariwisata Kota Sorong jika diukur dengan PDRB sektor pariwisata.

\section{Pembahasan}

Kunjungan wisatawan mancanegara ke Kabupaten Raja Ampat memberikan pengaruh yang sangat kecil terhadap kunjungan wisatawan mancanegara ke Kota Sorong. Hal ini menarik jika dikaitkan dengan kedudukan Kota Sorong sebagai kota transit bagi wisatawan yang berkunjung ke Kabupaten Raja Ampat, baik wisatawan mancanegara maupun wisatawan domestik. Berdasarkan laporan, sebagian wisatawan mancanegara menikmati obyek wisata di Kabupaten Raja Ampat dengan 
memanfaatkan liveaboard (BPS Kabupaten Raja Ampat, 2021). Berdasarkan hasil wawancara yang dilakukan penulis dengan awak liveboard, wisatawan yang berkunjung ke Raja Ampat dan memanfaatkan liveboard umumnya segera menuju kapal setelah mendarat di bandara Kota Sorong, tanpa meluangkan waktu lebih dulu di Kota Sorong. Demikian pula, sekembalinya dari perjalanan wisata di wilayah Kabupaten Raja Ampat, wisatawan segera menuju bandara tanpa meluangkan waktu di Kota Sorong. Selain itu, sebagian besar wisataawan mancanegara berkunjung ke Kabupaten Raja Ampat untuk berwisata alam selam. Beberapa pengusaha homestay di Kabupaten Raja Ampat menyatakan bahwa mereka memeberikan layanan jemputan langsung di Kota Sorong begitu wisatawan tiba di Kota Sorong, kemudian langsung menuju homestay di kampung di Raja Ampat. Dengan demikian, wisatawan yang datang ke Kabupaten Raja Ampat tidak meluangkan waktu sebagai wisatawan di Kota Sorong. Karena di Kota Sorong tidak tersedia objek wisata berjenis wisata alam selam, maka wisatawan mancanegara yang meminati wisata alam selam umumnya langsung ke pelabuhan ferri untuk kemudian ke Kabupaten Raja Ampat tanpa tinggal lebih dulu di Kota Sorong. Dengan demikian, dari segi skunjungan wisatawan mancanegara, Kota Sorong mendapat pengaruh yang sangat kecil dari perkembangan pariwisata Kabupaten Raja Ampat,

Hasil analisis mengenai pengaruh jumlah kunjunngan wisatawan mancanegara ke Kabupaten Raja terhadap jumlah kunjungan wisatawan mancanegara ke Kota Sorong dan pengaruh jumlah kunjungan wisatawan ke Kabupaten Raja Ampat dengan kunjungan wisatawan mancanegara ke Kota Sorong memberikan hasil yang kurang konsisten. Di satu pihak jumlah kunjungan wisatawan mancanegara di Kabupaten Raja Ampat memberian pengaruh yang sangat kecil terhadap jumlah kunjungan wisatawan mancanegara di Kota Sorong. Di lain pihak jumlah kunjunga wisatawan mancanegara di Kabupaten Raja Ampat memberikan pengaruh yang cukup besar terhadap jumlah wisatawan mancanegara yang menginap di Kota Sorong. Hasil yang kurang konsisten di sini adalah bahwa pertambahan jumlah wisatawan mancanegara yang menginap di Kota Sorong lebih besar daripada pertambahan jumlah wisatawan mancanegara yang berkunjung ke Kota Sorong bila jumlah wisatawan mancanegara ke Kabupaten Raja Ampat menjadi penduga.

Berdasaran hasil analisis, jumlah wisatawan domestik ke Kabupaten Raja Ampat memberikan pengaruh yang sangat besar kepada terhadap jumlah wisatawan domestik yang menginap di Kota Sorong. Hasil yang sangat mencolok dari analisis ini adalah bahwa jumlah wisatawan domestik yang menginap di Kota Sorong hampir lima kali lipat dibanding jumlah kunjungan wisatawan domestik ke Kabupaten Raja Ampat jika jumlah kunjungan wisatawan domestik ke Raja Ampat menjadi penduga. Berdasarkan wawancara semistruktural yang dilakukan selama penelitian lapangan, diperoleh informasi bahwa banyak kebocoran tarif masuk wisatawan Raja Ampat dari kalangan wisatawan domestik. Banyak wisatawan domestik yang tidak bersedia membayar tarif masuk wisata Kabupaten Raja Ampat. Tarif masuk wisata Kabupaten Raja Ampat bagi wisatawan domestik besarnya Rp 250.000 antara tahun 2007 dan 2013, dan $\mathrm{Rp} 500.000$ mulai tahun 2014 (Atmodjo et al., 2017). Data wisatawan domestik Kabupaten Raja Ampat berasal dari pungutan tarif masuk wisata di mana tidak semua wisatawan domesti membayar tarif maasuk, sedangkan data wisatawan domestik yang menginap di Kota Sorong adalah data realisasi reservasi. Dengan demikian, dapat disimpulkan bahwa dari segi kunjungan wisatawan domestik ke Kota Sorong, pariwisata Kabupaten Raja Ampat memberikan pengaruh yang cukup besar. Selain itu, hasil analisis memberikan indikasi adanya kebocoran tarif masuk wisata Kabupaten Raja Ampat yang cukup besar dari kalangan wisatawan domestik. Hal ini juga menjelaskan hasil analisis yang mengungkapkan bahwa jumlah kunjungan wisatawan ke Raja Ampat secara keseluruhan (mancanegara dan domestik) memberikan pengaruh yanh besar terhadap jumlah wisatawan yang menginap di Kota Sorong, baik mancanegara maupun domestik, di mana wisatawan domestik memberikan sumbangan terbesar dalam data wisatawan yang menginap di hotel di Kota Sorong.

Pengaruh jumlah kunjungan wisatawan Kabupaten Raja Ampat yang cukup besar terhadap jumlah kamar hotel konsisten dengan 
hasil analisis mengenai pengaruh kunjungan wisatawan Raja Ampat yang besar terhadap jumlah wisatawan yang menginap di hotel di Kota Sorong, baik wisatawan mancanegara maupun wisatawan domestik. Berdasarkan analisis terhadap dua variabel ini, yaitu jumlah wisatawan yang menginap di hotel di Kota Sorong dan jumlah kamar hotel di Kota Sorong, pariwisata Kabupaten Raja Ampat memberikan pengaruh yang cukup berarti terhadap sektor pariwisata Kota Sorong. Kedudukan Kota Sorong sebagai kota transit bagi wisatawan yang berkunjung ke Raja Ampat mendorong pengusaha akomodasi berinvestasi dengan menambah jumlah kamar, meskipun secara keseluruhan jumlah hotel (penyediaan akomodasi) tidak tumbuh secara nyata.

Meskipun pengaruh pariwisata Kabupaten Raja Ampat terhadap sektor pariwisata Kota Sorong cukup besar, pengaruhnya terhadap PDRB sektor pariwisata Kota Sorong sangat kecil. Dengan memperhatikan bahwa Kota Sorong merupakan kota transit bagi wisatawan yang berkunjung ke Kabupaten Raja Ampat, terbatasnya jumlah objek wisata Kota Sorong, terutama yang sesuai dengan minat wisatawan, menyebabkan wisatawan tidak banyak meluangkan waktu untuk berwisata di Kota Sorong, sehingga pengaruhnya terhadap PDRB sektor pariwisata Kota Sorong sangat kecil. Selain itu, pertumbuhan sektor-sektor lain jauh lebih besar dari sektor pariwisata Kota Sorong. Daya tarik wisata seperti Tembok Berlin tidak sesuai dengan minat wisatawan, terutama wisatawan mancanegara yang berkunjung ke Raja Ampat dan transit di Kota Sorong. Laporan BPS menyatakan bahwa kontribusi sektor pariwisata terhadap PDRB Kota Sorong sangat kecil. Pada Tahun 2009 kontribusi sektor pariwisata terhadap PDRB Kota Sorong hanya 0,58\% (BPS Kota Sorong, 2010). Pada tahun 2019 kontribusi sektor pariwisata terhadap PDRB Kota Sorong menurun sampai hanya $1,47 \%$ (BPS Kota Sorong, 2020)

Kajian ini menggunakan jumlah kunjungan wisatawan mancanegara, jumlah wisatawan yang menginap di hotel, baik wisatawan mancanegara maupun wisatawan domestik, jumlah kamar hotel, dan PDRB sektor pariwisata sebagai pendekatan terhadap perkembangan sektor pariwisata Kota Sorong. Industri pariwisata merupakan industri multi-sektor yang milibatkan sektor-sektor ekonomi lain. Transportasi merupakan salah satu sektor penting dalam industri pariwisata, karena pariwisata selalu memberikan konotasi perjalanan (traveling). Sarana dan prasaran transportasi berperan penting dalam industri pariwisata. Makan dan minum sebagai salah satu komponen penting dalam sektor pariwisata sudah diperhitungkan dalam PDRB sektor pariwisata dalam kajian ini. Namun sub-sektor penyediaan makan minum menggunakan input dari sektor perdagangan dan sektor pertanian. Kedua sektor ini belum disertakan dalam analisis peran pariwisata Kabupaten Raja Ampat alam perkembangan ekonomi Kota Sorong.

\section{KESIMPULAN}

Kedudukan geografis dan kondisi infrastruktur transportasi menyebabkan Kota Sorong menjadi kota transit bagi wisatawan yang henda berkunjung ke Kabupaten Raja Ampat. Secara umum pariwisata Kabupaten Raja Ampat yang turus tumbuh memberikan pengaruh yang cukup berarti bagi perkembangan sektor pariwisata Kota Sorong dari segi kunjungan wisatawan, jumlah wisatawan yang menginap di hotel, dan jumlah kamar hotel di Kota Sorong. Meskipun demikian, pertumbuhan pariwisata Kabupaten Raja Ampat tidak memberikan pengaruh yang berarti terhadap ekonomi Kota Sorong, dalam hal ini terhadap PDRB sektor pariwisata.

\section{DAFTAR PUSTAKA}

Aguayo, E. \& others. (2011). Impact of tourism on employment: An econometric model of 50 CEEB regions. Regional and Sectoral Economic Studies, 11(1), 3746.

Atmodjo, E., Lamers, M., \& Mol, A. (2017). Financing marine conservation tourism: Governing entrance fees in Raja Ampat, Indonesia. Marine Policy, 78, 181-188. https://doi.org/10.1016/j.marpol.2017.01 .023

BPS Kabupaten Raja Ampat. (2021). Kabupaten Raja Ampat Dalam Angka 2021. Badan Pusat Statistik Kabupaten Raja Ampat.

BPS Kota Sorong. (n.d.). Wisatawan (jiwa). BPS Kota Sorong. Retrieved November 17, 2021,

from 
https://sorongkota.bps.go.id/indicator/16 /294/2/wisatawan.html

BPS Kota Sorong. (2009). Kota Sorong Dalam Angka 2009. Badan Pusat Statistik Kota Sorong.

BPS Kota Sorong. (2010). Statistik Daerah Kota Sorong 2010. Badan Pusat Statistik Kota Sorong.

BPS Kota Sorong. (2013). Statistik Hotel Dan Tingkat Penghunian Kamar Hotel Kota Sorong 2013. Badan Pusat Statistik Kota Sorong.

BPS Kota Sorong. (2020). Statistik Daerah Kota Sorong 2020. Badan Pusat Statistik Kota Sorong.

Cahyadi, H. S. (2018). Tourism Economic Impact of South Lampung Regency. Journal of Indonesian Tourism, Hospitality and Recreation, 1(2), 106115.

Fredman, P., \& Yuan, M. (2011). Primary Economic Impacts at Three Spatial Levels: The Case of Fulufjället National Park, Sweden. Scandinavian Journal of Hospitality and Tourism, 11(sup1), 7486.

https://doi.org/10.1080/15022250.2011.6 29910

Llorca-Rodríguez, C. M., Casas-Jurado, A. C., \& García-Fernández, R. M. (2017). Tourism and poverty alleviation: An empirical analysis using panel data on Peru's departments. International Journal of Tourism Research, 19(6), 746-756.

https://doi.org/10.1002/jtr.2147

Njoya, E. T., \& Seetaram, N. (2017). Tourism Contribution to Poverty Alleviation in Kenya: A Dynamic Computable General Equilibrium Analysis. Journal of Travel
Research, 57, 513-524. https://doi.org/10.1177/00472875177003 17

Paolella, M. S. (2018). Linear models and timeseries analysis: Regression, ANOVA, ARMA and GARCH. John Wiley \& Sons.

Pemerintah Kabupaten Raja Ampat. (2014). Laporan Akhir Revisi Rencana Induk Pariwisata Daerah Kabupaten Raja Ampat. Pemerintah Kabupaten Raja Ampat.

Roudi, S., Arasli, H., \& Aadiri, S. S. (2019). New insights into an old issue examining the influence of tourism on economic growth: Evidence from selected small island developing states. Current Issues in Tourism, 22(11), 1280-1300.

Truong, V. D. (2014). Pro-Poor Tourism: Looking Backward as We Move Forward. Tourism Planning \& Development, 11(2), 228-242. https://doi.org/10.1080/21568316.2013.8 64996

Wiranatha, A. S., \& Suryawardani, M. A. and I. G. A. O. (2017). Impact of tourism leakage on the growth of economic sectors, employment and income distribution in Bali, Indonesia. International Journal of Economic Research, 14(8).

World Tourism Organization (UNWTO) (Ed.). (2020). UNWTO World Tourism Barometer and Statistical Annex, January 2020. UNWTO World Tourism Barometer, 18(1), 1-48. https://doi.org/10.18111/wtobarometeren g.2020.18.1.1. 